\section{SOI: $1.1 /$ TAS $\quad$ DOI: $10.15863 /$ TAS International Scientific Journal Theoretical \& Applied Science}

p-ISSN: 2308-4944 (print) $\quad$ e-ISSN: 2409-0085 (online)

Year: $2018 \quad$ Issue: $01 \quad$ Volume: 57

Published: $19.01 .2018 \quad \underline{\text { http://T-Science.org }}$
Ilhomiddin Abdukadirovich Rustamov

The senior teacher

Department of Social Studies

The Fergana branch of the Tashkent University of Information technologies

Fergana, Uzbekistan

\title{
ABU ALI IBN-SINO DOCTRINE IN THE CONTEXT FORMATION OF HARMONIOUSLY DEVELOPED PERSON
}

\begin{abstract}
In article, it is made attempt to investigate philosophical doctrine of Abu Ali Ibn Sino of the great thinker, the scientific of Central Asia. The author the basic attention gives to studying the doctrine of Ibn Sino in a context formation of harmoniously developed person. In work, it is underlined value of philosophical doctrine of the scientist in education of young generation in the conditions of a civil society.

Key words: Philosophy, Avicenna, spirituality, the person, youth, harmonious developments, a civil society.

Language: English

Citation: Rustamov IA (2018) ABU ALI IBN-SINO DOCTRINE IN THE CONTEXT FORMATION OF HARMONIOUSLY DEVELOPED PERSON. ISJ Theoretical \& Applied Science, 01 (57): 58-60.

Soi: http://s-o-i.org/1.1/TAS-01-57-11 Doi: crossef https://dx.doi.org/10.15863/TAS.2018.01.57.11
\end{abstract}

\section{INTRODUCTION}

In the conditions of development of a civil society in Uzbekistan, it is given particular attention formation of harmoniously developed person, and from this point of view, the great interest represents a number of aspects of philosophical doctrine of Ibn Sino. The culture which has developed in the ancient Middle Ages of the people of Central Asia was synthesis of many cultural wealth. The intensive versatile communications, which are carried out by the countries of this region, connected them with other cultures and promoted distribution in their territories of scientific achievements of other countries. On the Arabian language works of known scientists, including philosophers are translated. Substantially under the influence of development and creative reconsideration of the doctrine of Aristotle in a context of east cultures and own original ideas there was a philosophical doctrine - Ibn Sino.

\section{METHODOLOGY}

Creativity of Ibn Sino was developed in a difficult complex of scientifically philosophical tradition of Ancient Greek antiquity, Aristotle's especially philosophical heritage. The philosophical science should develop own, internally coordinated system authentic approaches, in relation to religion, to start with necessity of their harmonization. The logic acting as the tool of the organization of knowledge, received by means of speculation and experience became a basis of such system for Ibn
Sino. Thus the scientist believed, what even predictions have quite terrestrial though also extremely rare nature in the person, allowing their owner to compress all difficult way of transition from perception to generalization in the single certificate of comprehension. Special attention to logic allowed Ibn Sine to avoid immersing in primitive empiricism and to develop such methods of the theoretical analysis, as mental experiment and intuition. It is important to notice that Ibn Sino put forward specific ideologically theoretical and scientific problems. In its scientific researchers have concentrated and have received the integrated expression the basic achievements of scientists of Central Asia in different areas of knowledge. The philosophical doctrine of Avicenna has had huge influence on development of progressive scientific thought of the East and the West. «Abu Ali Ibn Sino - Avicenna who is well-known for that else those times, in X1 a century, for the first time performed surgical operations. The most important thing - its work « Canon of a medical science »of 500 years was studied in the most prestigious European high schools as the textbook for all students» [1.156].

From the point of view of a problem, formation of harmoniously developed person is of interest attempt of Ibn Sino to describe an image of the ideal person and to define a way of its perfection, intellectual development. The main difference of the person from all other creations he saw in possession force of reason. Better quality of the person he names 
inquisitiveness and calls people for expansion of their knowledge, wisdom comprehension for only the educated person is capable to make a correct choice between good and harm, to understand the place in the world, the human debt.

\section{RESULTS}

The higher degree of moral behavior is reached only when the blessing is managed for the sake of the blessing. The higher happiness is reached, when the person subordinates animal forces to force of reason, that is now of an eminence to reason. The happiness becomes accessible only at achievement of harmony and in «a practical part of soul», in each of the forces generating spiritually moral virtues.

In "Canon" of Ibn Sino underlines that since early years it is necessary for child «to impart feelings of kindness, honesty, responsibility, friendliness» [2.290]. The purpose of practical sciences, for example ethics - «knowledge of good and a management of behavior and affairs of people. All that exists, the scientist speaks, by the nature aspires to perfection. This aspiration also is kindly» [3.291]. As it is possible to see, ethical views of Ibn Sino are based on its political and philosophical ideas.

Above noted features of philosophical doctrine of Ibn Sino can essentially help modern conceptually methodological judgment of problems of moral education. Moral education as the socially psychological factor of public relations is the major precondition of formation of institutes of a civil society in independent Uzbekistan. Process formation of harmoniously developed person, being a phenomenon of public consciousness, it is interconnected with such making as the world, friendship, the consent in a society. It reflects mutual understanding and interaction degree between people, social institutes, or the states. Being closely connected with other characteristics of public consciousness, it at the same time takes a special place in their system has the specificity.

In the conditions of building democratic and a lawful state in the course of dialogue, each person faces other people, social groups etc. having rather various systems of values, belief and outlook. The certain theoretical and practical basis for the answer is given by the doctrine of Ibn Sino comprehended in modern contexts.

In other words, each concrete person to be assured of the freedom and the right to selfrealization should respect the corresponding rights of other people. Hence, such respect should concerns and other points of view. Differently, the morals are minimum possible and, hence, basic level respect, between people and other subjects of social relations. The morals are a basis for all other forms of constructive mutual relations between people, designate respect of mutual interests, interactions.
The morals act as a basis for the further cooperation. That is in this case the morals generate aspiration better to learn each other. The finding of the increasing quantity of things in common of interests of the co-operating parties will be result of this cognizance. Thus, the morals can generate the consent, cooperation etc. At the same, time the morals, developments in interaction are the phenomenon relative in the sense that it does not exclude positive rivalry between people. This rivalry means certain frameworks.

\section{DISCUSSION}

Scientific social scientists in the conditions of globalization try to solve secret of the person. It is necessary to notice that in this process the priority place in its research by right belongs to philosophers. The problem of moral education, formation of an inner world of the person takes an important place in creativity of Ibn Sino. An epoch in which lived and outstanding thinker-Encyclopaedist Abu Ali ибн created Sino, from an epoch of globalization, information is postponed by a huge time interval. However, the further time removes us, recent people, from an epoch of the great thinker; the big admiration causes its doctrines and scientific researches in the field of philosophy. Especially demanded there are questions of formation moral and an inner world during the critical periods of history, a particular in the conditions of deepening of democratic reforms, developments of a civil society.

Ibn Sino is to the greatest philosophers in the history of a world science. Its philosophical heritage is so deep and many-sided that is almost inexhaustible. It covers almost all areas of a philosophical science. In globalization conditions became actual the analysis of anthropological views in creativity of Ibn Sino. At the present stage of development of mankind, dynamic development of a science on a boundary of the third millennium has generated a number economic, social, the environmental problems menacing to existence of the person as a biological The modern philosophical thought should search for answers to these questions not only proceeding from possibilities of a civil society, but also leaning against wisdom and experience of the past epoch. The philosophy of Ibn Sino, especially its anthropological doctrine, promotes to find answers to the questions arising in the course of studying of separate aspects of the nature and activity of the modern person, and to global calls of market economy, social development as in it questions of life of the person are put in the foreground. Research of the nature, an origin and essence of the person and sense of his life and perfection of daily activity are the major philosophical questions as they mention problems of existence of the person. Activity of the person appears and in the conditions of a civil society not 


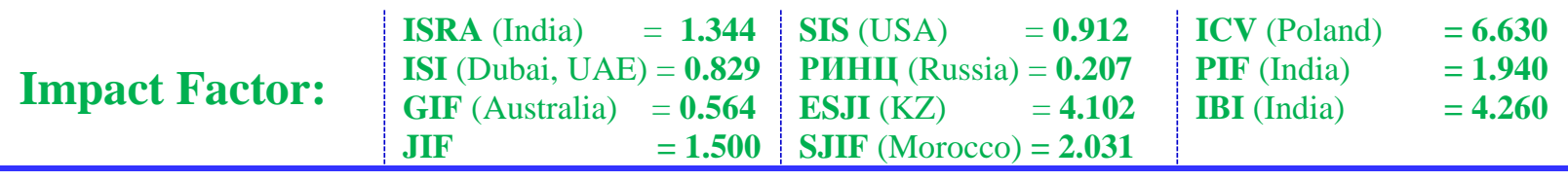

only as multiplane, as the major scientific problem, but also as the actual practical problem connected with preservation of humanity, the further its development.

It is necessary to underline that ideas put forward by the great thinker about essence and human nature, its informative possibilities have not lost the value and today, they have not only theoretical, but also practical value. It is necessary to notice that some of them for centuries forward have anticipated discoveries of scientific subsequent epoch and generations, all over the world. Modern researchers turn on ideas of the scientist, which only are comprehended and become now object of research modern a philosophical science.

Social, ethical, aesthetic views of Ibn Sino connected with social essence of the person is of great importance in research of problems formation of harmoniously developed person. Meanwhile in these areas creative genius Ibn Sino, its talent, skill, originality and originality as scientific Encyclopaedist was showed. Taking into account these factors it is necessary to look in a new fashion at a lifted problematic on formations of moral culture of the person, idea of greatness the maintenance of soul and the lowlands of its terrestrial passions reflected in products of the great scientist.

\section{CONCLUSIONS}

Thus, in the first: it is possible to tell that harmoniously developed person anyhow should exist in various forms of constructive mutual relation between people. In all these cases, it is necessary to start with вышеотмеченного the statement of Ibn Sino about necessary, intrinsic character of wide cooperation and mutual understanding between people, in a society as a whole.

In the second: moral education is the base, a basis to all forms of constructive mutual relations in a society.

In the third: in a wide spectrum of modern values of philosophical doctrine of Ibn Sino the important place deals with its correlation to modern problems of moral education and formation of harmoniously developed person, its importance as one of spiritually-conceptual sources of its judgment and realization.

\section{References:}

1. Karimov I.A. (2012) A way - deepening of democratic reforms and consecutive continuation of modernisation of the country. Tashkent, "Uzbekistan", 2012, Volume 20, p. 156.

2. (1986) The anthology of pedagogical thought, M. 1986. p. 290.

3. In the same place. p.291.

4. Abu Ali Ibn Sino (1980) The Selected Works. Dushanbe, «Irfon», 1980, V.1, p.32.

5. Saldadze A. Ibn Sino. (1985) (Avicenna) Pages of a Great Life. Tashkent. Publishing house of the literature and art of name Gafur Gulom, 1985 , p. 80-81, 378, 401, 402.

6. Boltaev M.N. (1980) Abu Ali Ibn Sino - the great thinker, scientific- encyclopaedist of the Medieval East.

7. Jumabayev Yu.D. (1988) Ethical Views of Abu Ali Ibn Sino // Triumph of a reason.-Dushanbe.
8. Karimov I.A. (2014) Vystuplenie Islama Karimova na otkrytii mezhdunarodnoy konferencii «Istoricheskoe nasledie uchenyh i mysliteley srednevekovogo Vostoka, ego rol' i znachenie dlya sovremennoy civilizacii».// Narodnoe slovo, 17 maya 2014.

9. Karimov I.A. (2008) Vysokaya duhovnost' sila neodolimaya. Tashkent, «Ma"naviyat», 2008.$308 \mathrm{p}$.

10. Mirziyoev Sh.M. (2016) Erkin va farovon, demokratik O`zbekiston davlatini birgalikda barpo etamiz. -T.: "O`zbekiston” NMIU, 2016. -p. 14.

11. Mirziyoev Sh.M. (2016) Konun ustuvorligi va inson manfaatlarini ta"minlash yurt taraққiyoti va halқ farovonligining garovi. - T.: O`zbekiston. 